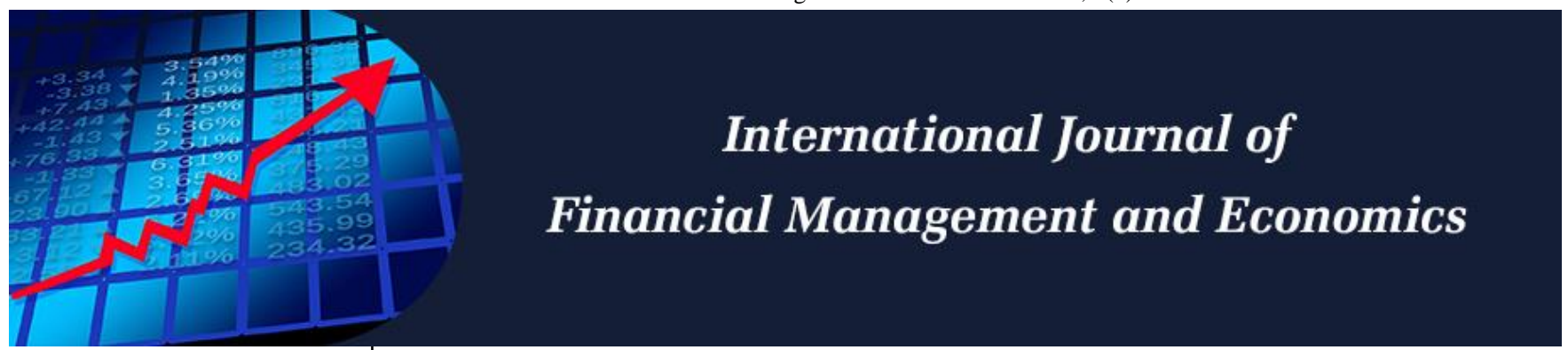

P-ISSN: 2617-9210 E-ISSN: $2617-9229$ IJFME 2021; 4(1): 06-15 Received: 05-11-2020 Accepted: 12-12-2020

Adamu Jibrilla Department of Economics, Adamawa State University Mubi, Nigeria

Priyanga Dunusinghe Department of Economics, University of Colombo, Sri Lanka

Corresponding Author: Adamu Jibrilla

Department of Economics, Adamawa State University Mubi, Nigeria

\section{Investors' origin and FDI Spillovers in Nigeria: Evidence from manufacturing sector}

\author{
Adamu Jibrilla and Priyanga Dunusinghe
}

DOI: https://doi.org/10.33545/26179210.2021.v4.i1.67

\begin{abstract}
The study of FDI spillover effects on domestic firms in developing countries has attracted the attention of many researchers over the past few decades. This study examines the role of country of origin of foreign investors in influencing FDI spillovers in the manufacturing sector in Nigeria using survey data from the World Bank Enterprise Survey published in 2018. Our study differs from previous FDI studies in the sense that existing studies in Nigeria did not pay attention to the country of origin of foreign investors in the analysis of FDI spillover effects. We follow the methodology of Javorcik (2004) in constructing the FDI spillover variables and use the augmented Cobb-Douglas production function to estimate the spillover effects of FDI on productivity of local firms where we incorporate investors' origin. Pooled OLS is used for the estimation of the parameters. The results of the regression analysis show that investors that originated from Europe have positive and statistically significant impact on productivity and also generate more technology spillovers compared to investors from Asia, Middle East and Africa. It is recommended that policymakers consider the source country of foreign investors when formulating FDI policies and further micro level studies are needed for more understanding how FDI spillovers affect the performance of local firms in developing countries especially in Africa.
\end{abstract}

Keywords: FDI, investors, origin, productivity, horizontal, backward, forward, Nigeria

\section{Introduction}

The importance of foreign direct investment (FDI) in facilitating economic growth and development has long been investigated. Many studies that have been conducted capture both direct and indirect benefits of FDI (Alfaro, 2016; Moran et al. 2018) [3, 10], have produced mixed results. FDI is associate with the transfer of modern technology which helps in the achieving the industrialisation agenda of developing countries through the direct and spillover effects on the local firms and the economy in general.

It has been argued that countries of origin of foreign investors are as good as the FDI itself because different countries have different levels of technological development, patent policies, labour regulations, willingness to share knowledge and the use of home country's inputs. These can have a significant influence on the degree of FDI spillover effects that could be generated in the host countries. Several studies have confirmed the significant influence of investors' country of origin on FDI spillovers in developing countries (see Gold et al., 2017; Javorcik \& Spatareanu, 2004; Monastiriotis, 2014; Ni et al., 2015; Takii, 2011) $[5,6,11,12]$. Despite the importance of country of origin of foreign investors in technology transfers, this issue has not been thoroughly examined in the context of Nigerian manufacturing sector.

Nigeria over the past two decades have implemented several investment liberalisation policies not only to attract FDI but also to facilitate technology transfers and domestic linkages ${ }^{[1]}$ to enhance productivity and growth. Having spent substantially on this course and sacrificed enough in terms of investment incentives, it becomes imperative to investigate the extent to which source countries of investors have influenced FDI spillovers in Nigeria. Although many studies have examined the effect of FDI on the Nigerian economy, the exiting FDI studies in Nigeria did not take into account the country of origin of foreign investors which is considered essential for technology spillovers.

\footnotetext{
1 The Nigerian government implemented local content requirement and backward integration policy in some manufacturing industries in 2002 in order to facilitate backward linkages and technology transfer.
} 
The objective of this study is to examine how countries of origin of foreign subsidiaries influence FDI spillover effects in Nigeria. This aims at providing a better understanding of the contribution or otherwise of foreign multinationals in Nigeria to technology and knowledge transfers based on their country of origin, and this is essential for policies that focuses on attracting FDI.

\section{Review of literature}

The theoretical models of both backward and forward linkages show that the share of inputs sourced by multinational enterprises in their host countries is related positively with the distance between their home countries and their production plant in the host countries (RodriguesClare, 1996; Markusen \& Venables, 1999). This suggests that the farther away the home countries of foreign investors to their host countries the higher the local sourcing and therefore domestic linkages and knowledge spillovers. This is because foreign subsidiaries are likely to import most of their intermediate inputs from home countries if the distance between home countries and host countries is small. Javorcik and Spatareanu (2004) ${ }^{[6]}$ specifically test this theoretical models in the case of Romania by considering investors' origins and categorising them into Europe, America and Asia. They find statistical evidence that investors that originated from Asia and America generate higher domestic linkages and FDI spillovers compared to investors from European countries and they attribute their findings to the fact that Asia and America are far away from Romania compared to Europe.

In the case of Nigeria Chen et al. (2015) reveal that many Chinese investors in Nigeria are widely dispersed across the country and this anti-clustered tendency created only few clustered-based supply chain relationships between them and local firms which is based mainly on technical assistance and support and not on supply chain linkages in the downstream and upstream sectors. In fact, it was revealed that most foreign firms from Asia particularly China have the tendency of integrating vertical production into their production lines by absorbing or creating both downstream and upstream production thereby reducing supply chain relationships with a consequential negative effect on spillovers and productivity of local firms. In addition, these authors reveal that many Chinese firms still import majority of their intermediate inputs or raw materials from China with only low-value and mostly heavy and bulky materials like rock for ceramics and wood for furniture are purchased from local suppliers. These actions are counterproductive for domestic suppliers and therefore reduce domestic linkages and FDI spillovers.

Similarly, study by Gold et al. (2017) ${ }^{[5]}$ was among the few studies that investigated the effects of investor's origin on FDI and FDI spillovers in developing countries. Using cross sectional data for 19 SSA countries, they examined whether south- south ${ }^{[2]}$ FDI and North-South FDI are different in generating productivity spillovers in SSA. Their results show that foreign subsidiaries, irrespective of their origin, were more efficient and productive than domestic firms and both south and north multinational investors generate

\footnotetext{
${ }^{2}$ The authors defined South investors to mean foreign investors from other African and developing countries while North investors are foreign investors from developed countries particularly OECD members.
}

technological spillovers and productivity enhancement for domestic firms in SSA. They also find that local firms receiving FDI from developed countries are more productive but subsidiaries of the southern origin generate more employment in their host countries and their parent companies provide more technological assistance.

Takii (2011) examines how FDI spillovers affect Indonesian manufacturing firms based on the country of origin of the multinational enterprises. The spillovers differ according to investor's origin as the multinational enterprises from eastern Asian countries generate significantly positive externalities while multinationals from non-Asian countries did not have a significant FDI spillover effect. Similarly, Japanese multinational enterprises generate less FDI spillovers compared to multinationals from east Asia.

In the same vein, Monastiriotis (2014) ${ }^{[11]}$ examines the productivity spillover effects of FDI originating from EU on the performance of firms in the countries neigbouring the EU to the east. Examining whether the FDI from the EU region produces spillover advantages in the host countries, decreases or increases spatial imbalances among its partners. Both the EU and non-EU FDI were examined and the results suggest that FDI originating from EU generates more spillover benefits and plays a distinctive role by significantly raising the productivity of domestic firms more than FDI of non-EU origin.

Similarly, it has been argued that the degree of FDI spillovers generated in a host country depends on the nature and origin of foreign direct investment. Abraham, Konings and Slootmaekers (2010), find evidence in the case of Chinese manufacturing firms that industries that receive foreign direct investment were more productive and there was evidence of positive horizontal spillover effects. The size of the spillover effects depends on the structure and country of origin of the foreign multinational investors where it is shown that Sino-foreign joint ventures generate larger spillover effects than the wholly owned foreign firms. $\mathrm{Ni}$ et al. (2015) study whether country of origin of FDI affects the productivity spillovers in Vietnam and show that foreign firms that originated from Asian countries generate more backward spillovers while foreign firms from Europe and North America appeared to have no significant influence on the backward FDI spillovers. In the case of horizontal FDI spillover effects, firms from the Association of South-East Asian Nations (ASEAN), East Asia and Europe reduce the productivity of Vietnamese firms operating in the same industries which could possibly be due to competitive and or labour turnover effects.

In the same vein, Amendolagine et al. (2017) examine the role of investor's country of origin in FDI spillovers and structural change in 19 SSA countries using cross sectional analysis. They provide a good analysis of differences and similarities between investors from OECD ${ }^{[3]}$ and BRICS ${ }^{[4]}$ countries regarding their ability to generate backward linkages, offer knowledge and technology transfers and training to domestic firms as well as employment, wages and demand for high skilled jobs. They find evidence that foreign investors from rich countries (OECD) generate more domestic linkages than investors that originated from developing countries (BRICS). Their study reveal that a

\footnotetext{
${ }^{3}$ Organisation for economic cooperation and development (OECD).

${ }^{4}$ Brazil, Russia, India, China and South Africa (BRICS).
} 
greater share of foreign investors engages in knowledge transfer, product and process upgrading as well as workforce training of domestic firms. Furthermore, foreign investors of OECD origin demand larger shares of highly skilled and qualified labour and offer better jobs than their counterparts from BRICS.

\section{Methodology \\ Data}

We used data from the World Bank's Enterprise Survey collected on manufacturing firms in Nigeria in 2007, 2009 and 2014 in the formal private sector. Stratified random sampling method was used to select the sample firms across all the six geo-political zones in Nigeria and structured questionnaires were administered through face-to-face interview with the employees and managers of the organisations. It is an unbalance panel that covers different sizes of the manufacturing firms such as micro, small, medium and large firms in different industries. For the purpose of this study, the micro firms were excluded from the analysis. Firms that have employees ranging between 5 and 20 are considered as small, firms with employees ranging between 20 and 99 are considered as medium while firms with employees above 99 are regarded as large firms as defined by the Enterprise Survey.

This study adopts the methodology employed by Javorcik
(2004) [6] to construct FDI spillover variables using the recent supply and use (SUT) table of Nigeria which was computed in 2010. This dataset is the only most recent and available which is relevant for our study. After data cleaning, 2,165 firms were used for the estimation in which pooled ordinary least squares (OLS) method was used. The possibility of heterogeneity among firms has been adequately corrected by including the industry/firm and size dummies. The origins of the foreign investors have been categorized into different regions. These regions are Europe, Asia, Middle East, India and Other. Dummy variables were created for each region and that takes the value of 1 if a firm originated from Europe, Asia, Middle East, India and Other and 0 otherwise. A dummy for local firms has been dropped from the estimation to avoid dummy variable trap. The investors' origins have been interacted with all the FDI spillover variables to determine if the effects of such FDI spillovers on productivity depend on the origin of the multinational investors.

\section{Model specification}

The estimated econometric model is built based on the Cobb-Douglas function and following the conventional specification of FDI spillover model adapted from Javorcik (2004) [6] where we modified and included investors' countries of origin as given in equation 1

$$
\begin{aligned}
\log (L P)_{i j r t}= & \phi_{0}+\phi_{1} \log (h z)_{i j r t}+\phi_{2} \log (b w)_{i j r t}+\phi_{3} \log (f w)_{i j r t}+\phi_{3} 1 O_{i j r t} \\
& +\phi_{4} \log (\text { FDISpillovers } * I O)_{i j r t}+\phi_{10} \ln Z_{i j r t}+\omega_{i}+\vartheta_{j}+\eta_{t}+u_{i j r t}
\end{aligned}
$$

Where LP is the labour productivity of a firm, hz, bw and fw are horizontal [5], backward and forward spillovers respectively. $\omega_{i}$ and $\vartheta_{j}$ capture the unobserved firm and industry heterogeneity effects while $u$ is the stochastic disturbance term which represents the unobserved factors that affect the productivity of domestic firms. IO stands for investors' origin. The interaction term, (FDISpillovers*10 $)_{i j t}$ means that the effect of FDI spillovers on the productivity of firms is conditional on the origin of multinational investors in firm $i$, in industry $j$, in region $r$ and period $t$. We construct labour productivity as the ratio of output over labour where total annual sales are used to represent output and total workers (production and nonproduction) have been used to denote labour.

\section{Horizontal spillover}

The horizontal spillover ${ }^{[6]}$ variable captures the degree of foreign presence in industry $j$ at time $t$. It is defined as the foreign share participation averaged over all firms in the industry, weighted by the output share of each firm in industry's output. Hence

$$
\begin{aligned}
& h z_{j t}=\left[\sum_{i \text { forall } i \in j} \text { Foreignshare }_{i t} *\right. \\
& \text { Output } \left._{i t}\right] / \sum_{\text {ifor all } i \in j} \text { Output }_{i t}
\end{aligned}
$$

\footnotetext{
${ }^{5}$ See Javorcik (2004) for comprehensive procedures on the construction of horizontal, backward and forward spillovers which were adopted in this study.

6 All the three spillover variables namely, horizontal, backward and forward spillovers are constructed following Javorcik (2004) and as applied by many researchers including Seyoum et al (2015), Lin, Liu, and Zhang (2009) and Zhang (2019)
}

The value of the horizontal variable tends to increase with the output of foreign-owned firm and the foreign-equity share in the firms.

\section{Backward spillover}

This variable represents the presence foreign firms in the industry where some of intermediate inputs are sourced locally. That is, local suppliers provide inputs to foreign multinationals in industry $j$. It captures the degree of potential contacts and interactions between local suppliers and their multinational customers in the downstream sectors. Thus,

$$
b w_{j t}=\sum_{k \neq \mathbf{j}} \vartheta_{j k} * h z_{k t}
$$

where $\vartheta_{j k}$ is the share of sector $j$ 's output that is supplied to sector $k$. It is an input-output coefficient to be taken from the Input-Output table for Nigeria. The coefficient was computed by excluding products supplied for final consumption but including imports of intermediate products. The value of the backward variable will be larger, the higher the foreign presence in sectors supplied by industry $j$ and the greater the share of intermediate inputs supplied to industries with presence of multinationals.

The construction of the Forward variable was also based on the approach suggested in the literature as shown in equation (4). 


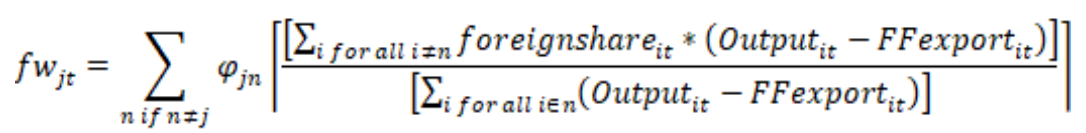

where $\varphi_{j n}$ is the proportion of inputs bought buy industry $j$ from industry $n$ in total inputs sourced by sector $j$, and FFexport $_{\text {it }}$ represents the share of foreign-owned firm's output that is exported. The coefficient, $\varphi_{j n}$ will be calculated from the input-output table. The $f w$ is the weighted share of output in supplying sectors that is produced by foreign-owned firms. Only intermediates sold in the domestic market are relevant to capture the extent to which outputs of firms with foreign presence are used as inputs by the domestic firms. Therefore, output produced by foreign-owned firms for export is excluded. The value of the variable tends to increase with the increase in the share of foreign affiliates in the output of domestic firm in the upstream sectors.

\section{Descriptive analysis}

\section{Distribution of manufacturing industries in Nigeria}

Our sample survey dataset provides a distribution of manufacturing firms based on the industries in the manufacturing sector in Nigeria. The distribution of manufacturing firms based on industries and ownership is essential because it gives an insight into the main destination industries of foreign investors in the manufacturing sector in Nigeria which may also influence the degree of FDI spillovers. This is because it is reasonable to expect much impactful technology spillovers within the high technology industries such as chemicals and pharmaceuticals, electronics, machinery and equipment and automobile industry. Similarly, the presence of foreign multinationals in medium technology industries such as rubber and plastics products, non-metallic and minerals products should also trigger substantial technology transfer. Concentration of foreign multinationals in low technology industries such as food and beverages, textile and garments, fabricated metal products (with the exception of weapons and ammunition), wood and furniture, paper and publishing may not facilitate significant technology transfer necessary for industrialisation of a developing country like Nigeria.

The information in table 1 shows that there are 10 manufacturing industries included in the survey sample divided according to domestic and foreign owned firms. There are 3,527 domestic owned firms representing 95 percent of all the firms included in the sample while the foreign owned firms are 179 representing the remaining 5 percent. For both domestic and foreign owned firms, food and beverage industry is the dominant industry representing about 20 percent and 24 percent of the firms respectively. This sample shows that the percentage of foreign subsidiaries in the manufacturing sector is higher in the food and beverage industry producing such items as vegetable oil, fruits and juices, baked food and bakery, alcoholic and non-alcoholic beverages, soft drinks, dairy products, snack foods than the domestic owned firms, which may not facilitate substantial technology transfer.

Table 1: Distribution of manufacturing firms by industries and ownership

\begin{tabular}{|c|c|c|c|c|}
\hline \multirow{2}{*}{ Industries } & \multicolumn{2}{|c|}{ Domestic Firms } & \multicolumn{2}{c|}{ Foreign Owned Firms } \\
\cline { 2 - 5 } & Frequency & Percent & Frequency & Percent \\
\hline Chemicals and pharmaceutics & 62 & 1.76 & 4 & 0 \\
\hline Electronics & 10 & 0.28 & 14 & 0 \\
\hline Fabricated Metal Products & 138 & 3.91 & 43 & 2.82 \\
\hline Food \& Beverage & 704 & 19.96 & 6 & 3.02 \\
\hline Metals and machinery & 385 & 10.92 & 28 & 15.64 \\
\hline Non-metallic and plastic materials & 348 & 9.87 & 29 & 16.20 \\
\hline Other Manufacturing & 498 & 14.12 & 15 & 8.38 \\
\hline Publishing & 126 & 3.57 & 16 & 8.94 \\
\hline Garments \& Textiles & 567 & 16.08 & & 24 \\
\hline Wood \& furniture & 689 & 19.54 & \multicolumn{2}{c}{13.41} \\
\hline Total & 3,527 & 100.00 & 179 & 100.00 \\
\hline
\end{tabular}

Source: Computed by the author based on data from the World Bank enterprise survey (2018)

The second dominant industry where local firms are more concentrated is the wood and furniture which hosts 564 manufacturing firms accounting for 16 percent of the locally owned firms in the sample. In the case of foreign subsidiaries, other manufacturing appears to be the second dominant industry where foreign owned firms are concentrated hosting 16 percent of them. Non-metallic and plastic materials industry is the third largest destination industry for foreign multinational investors in the manufacturing sector in Nigeria. This industry, which falls under the category of medium technology industry, hosts 15.64 percent of all the foreign subsidiaries included in the sample. On the other hand, garment and textile industry is the third dominant industry for locally owned firms in the sector hosting about 16 percent of the locally owned firms in the sample.
Similarly, foreign subsidiaries invest in wood and furniture industry in Nigeria which happens to be the fourth largest industry destination for foreign multinational enterprises hosting about 13 percent of the total foreign owned firms included in the sample. Other manufacturing industry appears to be the fourth largest industry for domestic owned firms representing about 14 percent of the total number of domestic owned manufacturing firms included in the sample. The table 1 also shows that there are no foreign subsidiaries in the electronics industry and only 4 foreign owned firms in the chemicals and pharmaceuticals industry representing only 2.23 percent of the foreign subsidiaries in the manufacturing sector. This shows that high technology industries attract only few foreign multinational enterprises which may not be good for a meaningful technology transfer. 
In summary, the information in table 1 shows that majority of the foreign subsidiaries in the manufacturing sector in Nigeria, representing about 79 percent of the foreign owned firms are concentrated in the low technology industries such as food and beverages, wood and furniture, garments and textile, fabricated metal products, publishing and other manufacturing. Only 5.58 percent of the foreign subsidiaries are in the high technology industries such as chemicals and pharmaceuticals, electronics as well as metals and machinery. Also, only 15.64 percent of the foreign owned firms are in the medium technology industries. The greater percentage of the foreign subsidiaries in the low technology industries is an indication that even if technology transfer takes place in the manufacturing sector, the quality of such technology transfer may not be high.

\section{Average performance of manufacturing firms}

The performance of manufacturing firms in Nigeria has been examined based on different characteristics such as size, ownership and country of origin of investors. Table 2 presents the annual average performance of firms based on size where it is shown that the performance indicators of the manufacturing firms based on productivity, annual turnover, employment of skilled and qualified workers as well as average annual wages per worker vary according to the sizes of the firms. This suggests the presence of heterogeneity in the performance of firms as large firms appear to be more productive, have more turnovers, employ more skilled workers and pay higher wages than medium and small firms.

Table 2: Annual average productivity growth of firms by size 2007-2014

\begin{tabular}{|c|c|c|c|c|c|c|}
\hline \multirow{2}{*}{ Variable } & \multicolumn{2}{|c|}{ Small Firms } & \multicolumn{2}{|c|}{ Medium Firms } & \multicolumn{2}{|c|}{ Large Firms } \\
\hline & Obs & Mean & Obs & Mean & Obs & Mean \\
\hline Log of annual labour productivity & 1,768 & $\begin{array}{l}12.821 \\
(0.941) \\
\end{array}$ & 565 & $\begin{array}{l}13.030 \\
(1.088) \\
\end{array}$ & 95 & $\begin{array}{l}14.252 \\
(1.627) \\
\end{array}$ \\
\hline Log of total annual sales & 1,873 & $\begin{array}{l}15.461 \\
(1.184)\end{array}$ & 600 & $\begin{array}{l}16.836 \\
(1.552)\end{array}$ & 86 & $\begin{array}{l}17.968 \\
(1.264)\end{array}$ \\
\hline Log of skilled \& qualified labour force & 1,771 & $\begin{array}{c}5.99266 \\
(4.295)\end{array}$ & 569 & $\begin{array}{c}18.175 \\
(14.334)\end{array}$ & 104 & $\begin{array}{l}19.638 \\
(2.271)\end{array}$ \\
\hline Log of total annual wages & 1,630 & $\begin{array}{l}14.107 \\
(0.744)\end{array}$ & 512 & $\begin{array}{l}15.627 \\
(0.896)\end{array}$ & 97 & $\begin{array}{c}117.938 \\
(251.976)\end{array}$ \\
\hline
\end{tabular}

Source: Author's computation using survey data from World Bank enterprise survey (2018). Note: The labour productivity is used which was calculated as the value added per worker

Small firms appear to be the least productive firms in the manufacturing sector based on the sample collected. The higher productivity and turnovers of the large firms may be connected to the fact that they employ more skilled and qualified workers and pay higher wages. More importantly, large firms are able to undertake research and development, employ modern and advanced technological equipment and they have better management practice compared to small and medium sized firms.

The heterogeneity in the performance across different manufacturing firm sizes in this analysis is consistent with findings from many previous studies. This heterogeneity issue has been adequately addressed in the regression analysis by constructing and incorporating size dummies across the different firm sizes in line with many previous studies.

Such differences in performance also manifest according to the ownership of firms categorized as domestic and foreign owned firms as reported in table 3 . In this case, foreign owned firms appear to be more productive and employ more highly skilled and qualified workers than locally owned firms. The average annual labour productivity of foreign subsidiaries is 13.485 which is higher than the 12.897 of domestic firms as presented in table 3 .

Table 3: Average performance of firms based on ownership, 2007-2014

\begin{tabular}{|c|c|c|c|c|c|c|}
\hline \multirow{2}{*}{ Variable } & \multicolumn{3}{|c|}{ Domestic Owned Firms } & \multicolumn{3}{c|}{ Foreign Owned Firms } \\
\cline { 2 - 6 } & Obs & Mean & Std & Obs & Mean & Std \\
\hline Log of annual labour productivity & 2,494 & 12.897 & 1.003 & 47 & 13.485 & 2.253 \\
\hline Log of total annual sales & 2,618 & 15.859 & 1.569 & 72 & 16.436 & 3.535 \\
\hline Log of total labour force & 2,616 & 22.266 & 99.918 & 72 & 93.694 & 182.00 \\
\hline Log of total annual wages & 2,311 & 14.459 & 1.257 & 30 & 17.276 & 1.905 \\
\hline Log of skilled \& qualified labour & 2,388 & 12.766 & 54.920 & 49 & 38.959 & 61.587 \\
\hline Log of annual expenditure of capital equipment & 2,341 & 13.667 & 2.041 & 48 & 14.374 & 5.747 \\
\hline \% of Material inputs \& supplies of local origin & 2,501 & 93.569 & 16.173 & 49 & 69.367 & 32.163 \\
\hline
\end{tabular}

Source: Author's computation using survey data from World Bank enterprise survey (2018).

Note: Log of total annual cost of labour per worker is used as wages which include cost of salaries, wages, bonuses and allowances.

Productivity is the log of value added per worker (Labour productivity).

Similarly, the higher productivity of foreign subsidiaries in the manufacturing sector in Nigeria may be associated with the fact that they pay higher average wages per worker which enables them to not only employ the highly skilled workers but also attract the most productive workers with years of experience from domestic owned firms in the same sector. They also invest more (14.374 percent) in capital equipment than domestic firms (13.667 percent) which include investment in advanced technological equipment as shown in table 3 . This result is also consistent with many previous findings in the area of FDI spillover studies which show that foreign owned firms are more productive and pay higher wages than domestic owned firms.

Another interesting indicator in table 3 is the percentage of material inputs or supplies of domestic origin which shows that domestic owned firms source 93.569 percent of their 
inputs from Nigeria while foreign subsidiaries source 69.367 percent of their inputs and supplies locally. This big percentage of local inputs and supplies of 69 percent by foreign multinationals in Nigeria is very essential for both the backward and forward FDI spillovers. It is also an indication that foreign owned firms generate large domestic linkages which may lead to a greater FDI spillover benefits in the manufacturing sector in Nigeria.

We also compute the average performance of firms based on their country/ region of origins as presented in table 4.

Table 4: Annual average productivity growth of firms by investors' country of origin 2007-2014

\begin{tabular}{|c|c|c|c|c|c|}
\hline Variable & OBS & Mean & Std. & Min & Max \\
\hline Europe & 7 & 15.037 & 1.870 & 11.875 & 17.003 \\
\hline Asia & 5 & 13.504 & 0.803 & 12.486 & 14.379 \\
\hline Middle East & 8 & 13.949 & 1.378 & 12.434 & 15.507 \\
\hline India & 12 & 13.481 & 1.193 & 11.723 & 16.133 \\
\hline Africa & 2,195 & 12.972 & 0.801 & 10.714 & 16.944 \\
\hline
\end{tabular}

Source: Author's computation using survey data from World Bank enterprise survey (2018).

Note: The labour productivity is used which was calculated as the value added per worker.

The result in table 4 shows that manufacturing firms that originated from European countries have higher average productivity compared to firms of Asian, Middle Eastern, Indian and African origins. This is followed by firms from the Middle East, then Asia, India and Africa. African manufacturing firms, which also include Nigerian owned firms, have the least average productivity as reported in table 4 which means that technology and knowledge transfers through FDI spillovers are highly needed to improve their productivity.

The higher productivity of foreign subsidiaries of European origin may also partly be attributed to the fact that they pay higher average wages as reported in table 5. Again, firms from Middle East pay the second higher wages after Europe. This is followed by the Indian firms then Asian firms while African owned firms pay the least average wages per worker.

Table 5: Annual average wages of firms by investors' country of origin, 2007-2014

\begin{tabular}{|c|c|c|c|c|c|}
\hline Variable & Obs & Mean & Std & Min & Max \\
\hline Europe & 7 & 13.158 & 1.248 & 11.335 & 14.795 \\
\hline Asia & 5 & 12.271 & 0.706 & 11.331 & 13.093 \\
\hline Middle East & 8 & 12.789 & 0.835 & 11.596 & 13.845 \\
\hline India & 12 & 12.288 & 0.978 & 10.645 & 14.537 \\
\hline Africa & 2,195 & 11.953 & 0.608 & 9.798 & 14.509 \\
\hline
\end{tabular}

Source: Author's computation using survey data from World Bank enterprise survey (2018).

Note: Log of total annual cost of labour per worker is used as wages which include cost of salaries, wages, bonuses and allowances.

Hence, even among the foreign subsidiaries operating in Nigeria, there is heterogeneity in terms of their productivity and payment of wages and these are important for policy makers especially when deciding on the best target regions for FDI that would bring and facilitate higher technology and knowledge transfer in order to improve the productivity of domestic firms. As argued in the literature, only the most productive foreign subsidiaries can generate more and significant FDI spillover benefits in the host country like Nigeria.

\section{Results and Discussion}

The origins of the foreign investors have been categorized into five regions. These regions are Europe, Asia, Middle East, India and Other. The investors' origins have been interacted with all the FDI spillover variables to determine if the effects of such FDI spillovers on productivity depend on the origin of the multinational investors. The regression was carried out using pooled OLS having corrected for possible heterogeneity among firms by including the industry/firm and size dummies. The result of the analysis is reported in table 6 where column 1, column 2 and column 3 contained the results for the interaction between backward spillover and FDI origin, horizontal spillover and FDI origin, and forward spillover and FDI origin respectively.

We also run a regression of the investor's country of origin on the FDI spillover variables to determine the effect of foreign investor's origin on FDI spillovers in the manufacturing sector in Nigeria. The result of the analysis is presented in table 7 where the dependent variables are the horizontal, backward and forward FDI spillovers.

The result in table 6 shows that the coefficients on foreign investors from Europe and Asia are positive and statistically significant at 1 percent level of significance indicating that investors from these regions positively affect the labour productivity in the manufacturing sector in Nigeria. The result is consistent for horizontal, backward and forward spillovers as reported in column 1-column 3 of table 6 .

Table 6: Result of investors' country of origin and FDI spill overs on productivity

\begin{tabular}{|c|c|c|c|}
\hline & \multicolumn{3}{|c|}{ Dependent Variable: Labour Productivity (Log of Value Added Per Worker) } \\
\hline & (column 1) & (column 2) & $($ column 3) \\
\hline Constant & $-0.458(2.090)$ & $3.563(1.346)$ & $4.968^{685}(1.542)$ \\
\hline Foreign Share (FDI) & $-0.128(0.138)$ & $-0.134(0.139)$ & $-0.054(0.130)$ \\
\hline Log of horizontal FDI spillover & $0.643^{* 64}(0.022)$ & $0.520^{6.56}(0.090)$ & $0.647^{* 68}(0.022)$ \\
\hline Log of backward FDI spillover & $-0.554^{* * 8}(0.072)$ & $-0.471^{* 34}(0.033)$ & $-0.477^{6.84}(0.033)$ \\
\hline
\end{tabular}




\begin{tabular}{|c|c|c|c|}
\hline Log of Forward FDI spillover & $0.436^{* 48}(0.023)$ & $0.436^{* * 8 *}(0.023)$ & $0.361^{* 88}(0.053)$ \\
\hline European & $10.788^{638}(2.044)$ & $6.780^{* * 8}(1.279)$ & $5.431^{* 3 *}(1.467)$ \\
\hline Asian & $9.711^{* 48}(1.498)$ & $4.495^{* * *}(0.757)$ & $3.353^{* * 6}(1.194)$ \\
\hline Indian & $1.036(1.235)$ & $0.591(0.759)$ & $0.759(0.636)$ \\
\hline Middle East & $2.334(2.042)$ & $1.255(1.063)$ & $1.684(0.733)$ \\
\hline Other & $2.453(1.938)$ & $1.907(1.393)$ & $1.178^{* *}(0.775)$ \\
\hline Backward spillover*European & $0.396^{* 48}(0.087)$ & & \\
\hline Backward spillover*Asian & $-0.241^{* *}(0.079)$ & & \\
\hline Backward spillover*Indian & $0.049(0.076)$ & & \\
\hline Backward spillover*Middle East & $0.008(0.094)$ & & \\
\hline Backward spillover*Africa & $0.084(0.065)$ & & \\
\hline Horizontal spillover*European & & $0.450^{* * 6}(0.106)$ & \\
\hline Horizontal spillover*Asian & & $-0.161^{*}(0.095)$ & \\
\hline Horizontal spillover*Indian & & $0.087(0.098)$ & \\
\hline Horizontal spillover*Middle East & & $0.047(0.110$ & \\
\hline Horizontal spillover*Africa & & $0.124(0.087)$ & \\
\hline Forward spillover*European & & & $0.342^{* * 8}(0.085)$ \\
\hline Forward spillover*Asian & & & $-0.134^{*}(0.079)$ \\
\hline Forward spillover*Indian & & & $0.029(0.063)$ \\
\hline Forward spillover*Middle East & & & $-0.017(0.065)$ \\
\hline Forward spillover*Africa & & & $0.079(0.049)$ \\
\hline Industry effects & Yes & Yes & Yes \\
\hline Size effect & Yes & Yes & Yes \\
\hline Year effects & Yes & Yes & Yes \\
\hline Observations & 2,165 & 2,165 & 2,165 \\
\hline$R^{2}$ & 0.72 & 0.72 & 0.72 \\
\hline
\end{tabular}

Note: $* * *$, and $* * *$ signify significant level at $10 \%, 5 \%$ and $1 \%$ respectively. Robust and cluster standard errors have been used to avoid heteroskedasticity and serial correlation. Pooled OLS was used for the estimation of models in table 9.

Foreign investors from India and Middle East have positive but statistically insignificant coefficients suggesting that they do not have significant impact on productivity in the manufacturing sector in Nigeria. This is the same for foreign firms from Other countries which appear to be positive in all the cases but statistically significant in only one case. In column 3 of table 6 , it is shown that foreign firms from Other regions increase productivity in the manufacturing sector.

The coefficient on the interaction term between backward FDI spillover and European firms produced an interesting result. The result in column 1 of table 6 shows that this coefficient is positive (0.396) and it is statistically significant at the $1 \%$ level of significance. This means that domestic suppliers of intermediate inputs benefit from their foreign customers provided the foreign firms are from European countries. This is consistent with Amendolagine et al. (2017) who find in a study of 19 SSA countries that foreign investors from rich countries (OECD) generate a higher share of domestic linkages with local suppliers in the downstream sectors compared to investors from less developed countries (BRICS). All this may be due to the fact that firms from developed regions employ more advanced technologies and produce more sophisticated and higher quality products, which according to the theoretical FDI spillover mechanisms developed by Rodriguez-Clare (1996) generate more positive backward linkages and spillovers in the host country.

In contrast, the coefficient on the interaction term between backward spillover and Asia is negative (-0.241) suggesting that firms from Asian countries reduces the productivity of domestic suppliers of inputs. This may possibly be due to the fact that most of firms from Asian countries import their intermediate inputs thereby affecting the domestic suppliers in the manufacturing sector in Nigeria. The result confirms the findings of Chen at al. (2016) in a cross sectional study in SSA where it was revealed that most firms from Asia especially China have the tendency of incorporating supply chain in their production lines thereby preventing backward spillovers from taking place. Since Nigeria is one of the largest destination of Chinese investors in Africa, the same tendency may likely take place as reflected in this study.

The effect of backward FDI spillover conditional on the investors from India, Middle East and other African countries is positive but statistically insignificant. This suggests that foreign investments of Indian, Middle Eastern and other African origins do not provide significant benefits to domestic suppliers of intermediate inputs in the manufacturing sector in Nigeria.

Similarly, in column 2 of table 6 , it is shown that the coefficient on the interaction term between horizontal FDI spillover and European is positive and statistically significant at $1 \%$ level while the coefficient on the interaction between horizontal and Asia is negative and weakly significant at $10 \%$ level. There is no statistically significant evidence that horizontal FDI spillover effect depends on foreign multinationals from India, Middle East and other African countries. Foreign subsidiaries from these 
regions do not appear to have a significant effect on competition, imitation and reverse engineering as the case may be.

On the other hand, foreign firms that originated from European countries increase the productivity of firms in Nigeria through the competition and imitation effect which is line with the findings of Gold et al. (2017) ${ }^{[5]}$ in a cross sectional study in SSA. They find that local firms that received FDI from developed countries experienced higher productivity compared to firms that received FDI from other regions. This is also consistent with Monastiriotis (2014) ${ }^{[11]}$ who finds that multinational firms from Europe generated more FDI productivity spillovers on the neigbouring countries' local firms than foreign firms from non-EU countries.

There is a strong statistical evidence of a positive effect of forward FDI spillover conditional on European as reported in column 3 of table 6 suggesting that foreign subsidiaries originating from European countries also offer benefits to their customers in the upstream sector. This suggests a significant technology spillover because domestic firms purchasing intermediate inputs from European foreign subsidiaries in Nigeria benefits from such relationship. High quality of inputs supplied by foreign firms that originated from European region and the possible training services received by their domestic customers may explain some of the reasons for their positive contribution to the productivity of domestic firms in Nigeria. This is also consistent with the findings of Amendolagine et al. (2017) who find that foreign firms originating from rich countries provide higher domestic linkages and spillover benefits by providing training to both their buyers and suppliers of inputs in SSA countries.

However, forward FDI spillover effect conditional on Asia is negative but weakly significant at the $10 \%$ level indicating that domestic firms that buy inputs from foreign firms of Asian origin experience productivity reduction. This may possibly be due to low quality of intermediate inputs that might have been supplied to domestic customers or inadequate guide and instructions by their foreign suppliers originating from Asia. The effect of forward FDI spillover conditional on Indian, Middle Eastern and other African firms is not statistically significant. This shows that buying inputs from foreign firms originating from India, Middle East and other African countries does not increase the productivity of domestic firms in the manufacturing sector in Nigeria.

Table 7: Result of the effects of investor's country of origin on FDI spillover variables

\begin{tabular}{|c|c|c|c|}
\hline & Horizontal Spillover (1) & Backward Spillover (2) & Forward Spillover (3) \\
\hline Constant & $\begin{array}{c}32.167 * * * \\
(5.464)\end{array}$ & $\begin{array}{c}45.181 * * * \\
(5.648)\end{array}$ & $\begin{array}{c}37.158 * * * \\
(6.200)\end{array}$ \\
\hline European & $\begin{array}{c}1.520 * * * \\
(0.518)\end{array}$ & $\begin{array}{c}1.620 * * * \\
(0.491)\end{array}$ & $\begin{array}{c}1.628^{* * *} \\
(0.449)\end{array}$ \\
\hline Asian & $\begin{array}{c}0.419 \\
(0.465)\end{array}$ & $\begin{array}{c}0.522 \\
(0.357)\end{array}$ & $\begin{array}{l}1.326 \\
(0.843)\end{array}$ \\
\hline Indian & $\begin{array}{c}0.585 \\
(0.531)\end{array}$ & $\begin{array}{c}0.336 \\
(0.660)\end{array}$ & $\begin{array}{c}0.494 \\
(0.669)\end{array}$ \\
\hline Middle East & $\begin{array}{c}0.125 \\
(0.340) \\
\end{array}$ & $\begin{array}{c}0.427 \\
(0.408) \\
\end{array}$ & $\begin{array}{l}1.530 * \\
(0.824) \\
\end{array}$ \\
\hline Others & $\begin{array}{c}-0.683 * * * \\
(0.207)\end{array}$ & $\begin{array}{c}-0.773 * * * \\
(0.252)\end{array}$ & $\begin{array}{c}-0.735^{* *} \\
(0.290)\end{array}$ \\
\hline Exporting firms & $\begin{array}{l}1.571 * * * \\
(0.208)\end{array}$ & $\begin{array}{l}1.503 * * \\
(0.225)\end{array}$ & $\begin{array}{l}1.640 * * * \\
(0.242)\end{array}$ \\
\hline Southern Region & $\begin{array}{c}0.237 * * * \\
(0.048)\end{array}$ & $\begin{array}{c}0.137 * * * \\
(0.052)\end{array}$ & $\begin{array}{c}0.023 \\
(0.055)\end{array}$ \\
\hline Firm's Age & $\begin{array}{c}-0.009 * * * \\
(0.003)\end{array}$ & $\begin{array}{c}-0.008 * * * \\
(0.003)\end{array}$ & $\begin{array}{c}-0.011 * * \\
(0.003)\end{array}$ \\
\hline Medium size firms & $\begin{array}{c}1.385^{* * *} \\
(0.062)\end{array}$ & $\begin{array}{c}1.390 \\
(0.065) \\
\end{array}$ & $\begin{array}{c}1.373 * * * \\
(0.069)\end{array}$ \\
\hline Large firms & $\begin{array}{c}3.420 * * * \\
(0.208)\end{array}$ & $\begin{array}{c}3.484 * * * \\
(0.227)\end{array}$ & $\begin{array}{c}3.543 * * * \\
(0.243)\end{array}$ \\
\hline Industry effects & Yes & Yes & Yes \\
\hline Size effect & Yes & Yes & Yes \\
\hline Year effects & Yes & Yes & Yes \\
\hline Observations & 2,132 & 2,132 & 2,132 \\
\hline$R^{2}$ & 0.47 & 0.44 & 0.41 \\
\hline
\end{tabular}

Note: $*, * *$, and $* * *$ signify significant level at $10 \%, 5 \%$ and $1 \%$ respectively. Robust and cluster standard errors have been used to avoid heteroskedasticity and serial correlation. Pooled OLS was used for this estimation and the dependent variables are the log horizontal, backward and forward spillovesr

Table 7 provides the estimated results of the direct effect of the country of origin of investors on FDI spillovers in the manufacturing sector in Nigeria. The results in column 1-3 show that foreign subsidiaries of European origin generate more FDI spillovers compared to foreign subsidiaries from other African countries. The coefficients on European are positive and strongly significant at $1 \%$ level for all the three types of FDI spillovers. This indicates that foreign subsidiaries from European countries are important in facilitating horizontal spillover possibly through competition and imitation since these subsidiaries are usually more technologically advanced and highly competitive in the manufacturing industries. Foreign firms of European origin also provide benefits to their domestic suppliers of intermediate inputs as well as their domestic buyers of intermediate inputs in the Nigerian manufacturing 
sector. Hence, European foreign subsidiaries increase the supply chain relationship in the manufacturing sector in Nigeria.

Asia, India and Middle East have a positive effect on the horizontal, backward and forward FDI spillovers but only the Middle East has a weakly significant impact on the FDI forward spillover as reported in column 3 of table 7 . This means that foreign subsidiaries from these regions only increase the supply relationship in the upstream sector where domestic buyers of intermediate inputs benefit from purchasing such inputs from foreign subsidiaries originating from the subsidiaries originating from the Middle East. Subsidiaries from originating from Asia and India did not significantly affect either the competition or supply chain relationships in the manufacturing sector in Nigeria

In contrast, the coefficients on Others are negative and statistically significant in all the cases suggesting that foreign subsidiaries from other regions have a negative effect on horizontal, backward and forward FDI spillovers in the manufacturing sector in Nigeria. This indicates that foreign firms from other regions are not competitive enough to trigger much competition in the same industries in which they operate with domestic firms and they tend to reduce domestic linkages in the downstream sector.

The control variables in table 7 appear to have a significant effect on FDI spillovers. Exporting firms have a positive and strongly significant effect on spillovers as reported in column 1-3 where exporting firms lead to increase in competition and supply chain relationship both in the upstream and downstream sectors. The magnitudes of the effect are significantly large because increase in exporting firm by 1 is associated with increase in horizontal spillover (either through competition, imitation and labour turnover) by 157 percent, increase in backward linkages by 150 percent and increase in forward linkages by 164 percent. Since exporting firms are an indicator variable, it means that exporting firms increase competition, backward spillover and forward spillover more than non-exporting firms by 157 percent, 151 percent and 165 percent respectively which are statistically significant at the $1 \%$ level. This is consistent with theory and literature where it has been argued that exporting firms are more productive, competitive and innovative than non-exporting firms because of their international exposer to modern technology and foreign competition.

Similarly, firms located in the southern region are more competitive and generate more backward linkages compared to firms in the northern region, but there seems to be no difference between them in generating forward linkages. The result shows that southern firms are 24 percent more competitive and have more imitation capabilities than northern firms and also generate more backward linkages than northern firms by 14 percent. The coefficients on firm's age are negative in all the cases indicating that younger firms are likely to more competitive, and generate more backward and forward linkages than older firms. Though the coefficients are statistically significant at $1 \%$, the size of the effect is very small, $-0.009,-0.008$ and -0.011 respectively suggesting that the effect of firm's age on FDI spillovers is extremely small.

Interestingly, there is evidence that the effect of firm's size on FDI spillovers is also statistically significant at $1 \%$ level as both medium and large firms generate more horizontal, backward and forward spillovers than small firms. Medium firms appear to be more competitive and have better imitation ability than small firms and they are 139 percent and 137 percent better in generating more backward and forward linkages. The coefficients of large firms are even higher significantly than that of the medium firms. The magnitudes of the effect of large firms are higher than that of medium size firms and they are more competitive than small firms by 342 percent, generate more backward and forward spillovers by 348 percent and 354 percent respectively.

\section{Conclusion}

The study shows the importance of country of origin in influencing FDI spillover effects in terms of technology and knowledge transfers in the manufacturing sector in Nigeria. Foreign firms originating from Europe positively affect FDI spillovers by increasing the productivity of firms in Nigeria and generating more linkages whereas firms that originated from Asia have a negative effect on FDI spillovers in Nigeria. Similarly, there is no statistical evidence that firms that originated from Middle East, India and others have significant influence on FDI spillovers in the manufacturing sector in Nigeria. The policy implications of these findings are that policymakers aiming at attracting more FDI into the country have to consider the source country of the investors and negotiate the potential spillover benefits to the economy. Researchers could also put emphasis on in-depth micro level analysis of FDI in effect developing countries since this area is still under-studied.

\section{References}

1. Abraham F, Konings J, Slootmaekers V. FDI spillovers in the Chinese manufacturing sector: Evidence of firm heterogeneity 1. Economics

of Transition 2010;18(1):143-182.

2. Amendolagine V, Coniglio ND, Seric A. Foreign direct investment and structural change in Africa: Does origin of investors matter? In Foreign capital flows and economic development in Africa. Palgrave Macmillan, New York 2017, P97-124.

3. Alfaro L, Chen MX. The global agglomeration of multinational firms. Journal of International Economics 2014;94(2):263-276.

4. Chen G, Geiger M, Fu M. Manufacturing FDI in SubSaharan Africa: trends, determinants, and impacts. The World Bank 2015.

5. Gold R, Görg H, Hanley A, Seric A. South-South FDI: is it really different? Review of World Economics 2017;153(4):657-673.

6. Javorcik BS. Does foreign direct investment increase the productivity of domestic firms? In search of spillovers through backward linkages. American economic review 2004;94(3):605-627.

7. Javorcik BS, Spatareanu M. Does it matter where you come from? Vertical spillovers from foreign direct investment and the origin of investors. Journal of Development Economics 2011;96(1):126-138.

8. Lin P, Liu Z, Zhang Y. Do Chinese domestic firms benefit from FDI inflow?: Evidence of horizontal and vertical spillovers. China economic review 2009;20(4):677-691.

9. Markusen JR, Venables AJ. Foreign direct investment as a catalyst for industrial development. European economic review 1999;43(2):335-356. 
10. Moran T, Görg H, Seric A, Krieger-Boden C. Attracting FDI in middle-skilled supply chains. Economics: The Open-Access, Open-Assessment EJournal 2018;12(26):1-9.

11. Monastiriotis V. Origin of FDI and domestic productivity spillovers: does European FDI have a 'productivity advantage' in the ENP countries? LEQS Paper 2014, P70.

12. Ni B, Spatareanu M, Manole V, Otsuki T, Yamada H. How Will the Origin of FDI Affect Domestic Firms' TFP?-Evidence from Vietnam. Osaka University Working Paper 2015. http://s3.amazonaws.com/academia.edu.documents/400 66563/How_Will_the_Origin_of_FDI_revise_2015102 0. pdf.

13. Rodriguez-Clare A. Multinationals, linkages, and economic development. The American Economic Review 1996, P852-873.

14. Seyoum M, Wu R, Yang L. Technology spillovers from Chinese outward direct investment: The case of Ethiopia. China Economic Review 2015;33:35-49.

15. Takii S. Do FDI spillovers vary among home economies? Evidence from Indonesian manufacturing. Journal of Asian Economics 2011;22(2):152-163.

16. Zhang Y. Institutions, Firm Characteristics, and FDI Spillovers. Emerging Markets Finance

and Trade 2019;55(5):1109-1136. 